\title{
Methodical Guidelines for the Design of Roundabouts in Lithuania
}

\author{
Aja Tumavičèa, Svaja Kaniušènienè $\dot{e}^{\mathrm{a}}$, Aurimas Šiukščius ${ }^{\mathrm{b}}$ \\ ${ }^{a}$ Vilnius Gediminas Technical University Faculty of Environmental Engineering Road Research Institute, Linkmeny str. 28, \\ VI corps, 5th floor, 08217 Vilnius , Lithuania \\ " "ViaCon Baltic" Ltd, Perkūnkiemio 4a, 12128 Vilnius, Lithuania
}

\begin{abstract}
During the last decade roundabouts served the purpose to be the one of the safest and to have the highest capacity of all at-grade intersections. Unfortunately, until now Lithuania had no detail design standards adapted specially for roundabouts, moreover, there was no clear vision what construction and design principles should be used for roundabouts. This article presents analysis of roundabout design and construction methods in Lithuania. Methodical Guidelines for the Design of Roundabouts proposes how to classify roundabouts into five different types. Also, it proposes the main principles and guidelines for roundabout design adapted for the use in Lithuania.
\end{abstract}

Keywords: roundabout; mini roundabout; small roundabout; two lane small roundabout; large roundabout; turbo roundabout.

\section{Introduction}

In 2011, Lithuania prepared the National Traffic Safety Development Program for 2011-2017. The strategic objective of this program is to improve the traffic safety situation, so that by the number of people killed on the roads per 1 million population Lithuania were between the average of the 10 EU states showing the best results in this field (or no more than 60 people killed/1 million population) [1].

For the development of specialists in the Baltic Sea region the project BALTRIS was launched which concentrates on the knowledge and experience exchange, as well as on the joint creation of safety administration procedures for road infrastructure [2]. Also, different means for the road users are applied, for example, fines for the breach of traffic rules, video cameras for the fixation of those breaches. But all these measures are not enough to ensure traffic safety, therefore, there is a need for the research of new methods to increase traffic safety. One of them could be the development of road geometric parameters and road installation, especially at intersections.

Intersections are one of the most dangerous places at the road network [3]. At intersections traffic flows come in contact with each other, thus, they are the potential place for traffic accidents. The higher traffic volume, the worse driving culture and the less information drivers have and if the intersection design elements are not properly chosen, the road users make mistakes and traffic accidents happen.

The highest accident rate is represented by uncontrolled intersections, also conflicts happen very often and their capacity is low [4]. The research on road network safety levels at intersections showed that the highest average accident rate was measured at four-leg at-grade intersections and the lowest - at grade-separated intersections [1]. But the construction of the latter is quite expensive, thus, there is a need for the solutions of at-grade intersections until it is possible depending on road capacity and safety. A good solution could be a modern roundabout.

Roundabouts, in comparison to four-leg intersections, have less conflict points. The latter has 32 and the one traffic lane roundabout has 4 times less, i.e. 8. Also, such roundabouts have no intersecting traffic flows, in the results of which collisions could be most dangerous.

Modern roundabout allows a free traffic movement through the carriageway. In this case, there is no need for the driver to change traffic lane or join the fast going traffic flow, but to wait for a proper gap in the slow traffic flow [5].

Corresponding author: Aja Tumavičè. E-mail address: aja.tumavice@vgtu.lt

http://dx.doi.org/10.3846/enviro.2014.171

(C) 2014 The Authors. Published by VGTU Press. This is an open-access article distributed under the terms of the Creative Commons Attribution License, which permits unrestricted use, distribution, and reproduction in any medium, provided the original author and source are credited. 
Safe and effective use of roundabouts depend on the speed reduction measures [5]. Also, it is important, especially in the cities, that roundabout construction does not require lot of space. The optimum speed at these roundabouts is about $16-$ $30 \mathrm{~km} / \mathrm{h}$. If the traffic accident happens at this speed, in most cases it is damage-only - without injury or fatality [6].

The first roundabouts in the cities of Lithuania were designed in 1970-1994 according to the standard design documents for the two lane entry and three lane exit recommendations. Those roundabouts were enough to satisfy the vehicle ownership level of up to $160-180 \mathrm{veh} / 1000$ population [7]. But, the negative opinion towards roundabouts, which was formed because of uncomfortable old-fashioned roundabouts, is still popular [6], [5].

Despite the struggle for the safe traffic in Lithuania, accidents, where people are injured or killed, are still very frequent. Therefore, a constant research is carried out how to reduce the number of traffic accidents or to minimize their consequences.

\section{Capacity and traffic safety of roundabouts}

Roundabouts can be classified into mini roundabouts, small roundabouts, two lane small roundabouts, large roundabouts and turbo roundabout. Roundabouts can be also classified by their location: in built-up areas, unbuilt areas or at the approaches to the built-up areas. Besides, specific non-typical roundabouts can be constructed (e.g. oval-shaped).

Two lane roundabouts are safer and more efficient in terms of their capacity than the conventional four-leg intersections. However, they are less safe though with a higher capacity than the single lane roundabouts. In order to ensure a higher capacity and at the same time to ensure maximum traffic safety Netherlands has created turbo roundabouts that are getting more and more popular in the world.

It was determined that turbo roundabouts are more efficient in terms of their capacity than one lane roundabouts but less efficient than two lane roundabouts. On the other hand, compared to the latter, they offer a better speed control and have less conflict points [8].

A four lane turbo roundabout has 6 merging, 4 separating and 4 intersecting points of conflict. In 2011, Slovenia had 5 turbo roundabouts of a new type. Turbo roundabouts satisfied the needs owing to their high capacity and especially large safety level, however, specific problems were faced related to the cleaning of snow in winter [9].

The number of conflict points at roundabout depends on traffic volume and traffic flow distribution between different exits, also on the diameter of roundabout; when the diameter of roundabout is $99 \mathrm{~m}$ the number of conflict points amounts to 72 [7]. Modern roundabouts can be provided with the diameter of 13 to $60 \mathrm{~m}$. This depends of the type of roundabout [4]. The larger roundabout diameter the higher average speed of all types of vehicles [5].

The safest is a modern one lane roundabout. On the other hand, its capacity is rather limited: up to approximately 2500 veh/day [10].

The highest capacity of at-grade intersections is represented by the traffic-light controlled roundabouts. In Hungary, after this type of roundabouts was built in 2006 , it was determined that the delays at those roundabouts were significantly reduced, but the number of non-severe accidents was increased. Accidents occur when the drivers enter the roundabout without being sure that they go in a right direction and, consequently, they change the lane within a roundabout zone [11].

Traffic-light controlled roundabouts have higher capacity, but they also have a higher risk of damage-only accidents. In case of an accident the traffic jams may occur before the accident consequences are eliminated. Therefore, it is necessary to take into consideration local conditions and to look for solutions to ensure maximum capacity and traffic safety.

In search of solutions to improve roundabouts, continuous improvement of their design principles is carried out. For example, in order to increase a capacity of one lane roundabout it is possible to [10]:

- Equip it with the right-turn traffic lanes (bypasses) and, thus, eliminating part of traffic flows from a circular carriageway. On the other hand, those traffic lanes occupy more space and they should be avoided, especially in the built-up areas with the intensive flow of pedestrians and bicyclists, as this reduces their traffic safety;

- To convert it to a semi (the lanes are not marked) or standard (with the marked traffic lanes) two lane roundabout. Such roundabouts have a higher accident risk.

It is not recommended for suburban roundabouts to be equipped with one traffic lane since in case of accident the roundabout is paralyzed for 40-60 minutes [7].

Roundabouts shall be also adapted to the other road users, especially to a comfortable and safe traffic of vulnerable road users (pedestrians and bicyclists).

Since vehicle speeds at modern roundabouts are not high it makes no difficulties to build pedestrian crossings or passages to ensure pedestrian safety. The legs of roundabouts can be provided with safety islands to help the pedestrians to cross the carriageway [6].

Roundabouts where bicycle traffic is guided to the bicycle lanes (in a circular carriageway they are separated only by marking) are the most unsafe. Less dangerous for bicyclists are roundabouts where bicycle traffic is organized in a general flow, by the separated bicycle tracks or partly separated bicycle tracks [12]. It was determined that the safest roundabout for bicyclists is that where they travel on bicycle tracks [13].

When selecting the type of roundabout it is very important to take into consideration local conditions, the existing and the predicted traffic volume. A special attention shall be paid to ensure safety of the vulnerable road users, for example, by designing special engineering measures. 


\section{Implementation of roundabouts in Lithuania}

Till now Lithuania had no detail regulations for the design and construction of roundabouts. The following normative documents were used to design and construct roundabouts: Road Intersections R-36 (Automobilių kelių sankryžos R-36) [14] (adopted in 2002) and Recommendations for the Design and Use of Engineering Traffic Safety Measures R ISEP 10 (Inžinerinių saugaus eismo priemonių projektavimo ir naudojimo rekomendacijos) [15] (adopted in 2010). The both documents contained only a small amount of regulations on the structural elements of roundabouts, the criteria for selecting the type of roundabout were not clear. The documents gave different design elements and different classification of intersections.

Besides, Lithuania still has no regulated measures which would help to improve the quality of public transport services at roundabouts. There are also no detail regulations on how to organize the traffic of vulnerable road users at roundabouts. Therefore, the planning was usually chaotic, unsafe, taking into consideration not all the relevant circumstances, therefore when designing, constructing, maintaining and using roundabouts a number of problems were faced. For example, the width of carriageway at the most Lithuanian roundabouts is less than the recommended one [16].

A problem was also faced when building a new type of turbo roundabouts in Lithuania. For example, the traffic at the newly erected turbo roundabouts is somewhat chaotic since the drivers do not know how to use them, they are not sure which the road users have the priority. Both of the already built turbo roundabouts have a lane divider which is not elevated: it is only milled and painted in a red conspicuous colour. This solution is insufficient since the lanes can be easily crossed by the drivers, and this is resulted in driving errors. Many drivers, having entered the right entry, cross the milled lane and drive straight by the inner lane. Such errors cause accident situations since the drivers travelling by the inner lane do not expect this manoeuvre. Besides, the curvature of driving trajectory is not enough and the driving speed is not reduced. In winter the lane divider will be completely invisible, the situation will get even worse and will result in unsafe and chaotic traffic.

Also, when designing and building roundabouts Lithuania often faces the problem of land: the adjacent land plots are built-up or private, and it is complicated to insert the roundabout into the existing free spaces. For this reason, the inner and outer radii as well as the entry and exit radii of roundabouts are minimum and do not meet the current requirements. If the carriageway is too narrow, it is more complicated to pass through the roundabout, the heavyweight oversize vehicles are forced to ride up on the block pavement, and sometimes even on the road kerbs or pedestrian paths. It was determined that the least damaged roundabout elements are: carriageway, road structures and pavement. $80 \%$ of roundabout pavements have no defects. The largest defects were found in road kerbs. Only $38 \%$ of roundabouts have no kerb defects, whereas, $48 \%$ of roundabouts represent small defects [16].

Incomprehensive, unclear and contradictory regulations have caused both design and construction errors. Failing a unique classification of roundabouts they were often built in a different way, thus, sometimes they misled road users. Besides, the proportions of design elements were not always properly planned what resulted in a complicated passage of certain vehicles or, on the contrary, there was a possibility to take a too high speed and the roundabout lost its main advantage - safe traffic.

\section{Regulations on the design of roundabouts in Lithuania}

In 2012, Lithuanian Road Administration under the Ministry of Transport and Communications adopted the Methodical Guidelines for the Design of Roundabouts MN ŽSP 12 (Žiedinių sankryžų projektavimo metodiniai nurodymai) [15].

The above document gives a new modern classification of roundabouts, introduces a new approach to the traffic of bicyclists, pedestrians and public transport and their safety at roundabouts, establishes the main principles of how to organize the control of roundabouts by traffic-lights as well as road signs. The guidelines also describe structural solutions and materials for the roundabouts, gives new regulations which will help to construct roundabouts even under complicated local conditions. For example, in case where several roundabouts are situated one after another, the left turns from/to the yards or minor roads may be prohibited. But only in case if the roundabout has good turning-round possibilities for the heavy vehicles.

The above mentioned methodical guidelines classify roundabouts according to their location - in built-up or unbuilt area (criteria for the use of roundabouts differ and their design principles are also partly different). Roundabouts are also classified by their size. The types and main characteristics of roundabouts are given in Table 1, the principle schemes are shown in Fig. 1.

The new methodical guidelines give general traffic volume of roundabouts at which the roundabouts of particular type will have enough capacity and will ensure traffic quality. Also, criteria for the use and selection of roundabouts are presented. Since the main and one of the most suitable type of roundabout is a small roundabout, based on the criteria for the use of small roundabouts it is essentially decided if a roundabout is worth planning, designing and building. If the criteria for the construction of a small roundabout are satisfied, there is a built-up area, the speed limit is $\leq 50 \mathrm{~km} / \mathrm{h}$ but the free space is not enough a very small roundabout can be built. If the capacity of a small roundabout is not sufficient and it is not possible to increase it by building bypasses, in such case a turbo roundabout or a two lane small roundabout should be built. 
Table 1. Types of roundabouts, their characteristics

\begin{tabular}{|c|c|c|c|c|c|c|}
\hline \multirow{2}{*}{ Roundabout type } & \multicolumn{2}{|c|}{ Outside diameter $D$} & \multirow{2}{*}{$\begin{array}{l}\text { Number of } \\
\text { lanes on circular } \\
\text { carriageway }\end{array}$} & \multirow{2}{*}{$\begin{array}{l}\text { Number of } \\
\text { lanes on } \\
\text { entry/exit }\end{array}$} & \multirow{2}{*}{ Bypasses } & \multirow{2}{*}{ Traffic lights } \\
\hline & Built-up area & Unbuilt area & & & & \\
\hline $\begin{array}{l}\text { Mini roundabout }{ }^{a} \\
\text { (see Figure } 1 \mathrm{a})\end{array}$ & $D=13-22$ & - & 1 & $1 / 1$ & usually not & undefined \\
\hline $\begin{array}{l}\text { Small roundabout } \\
\text { (see Figure } 1 \mathrm{~b} \text { ) }\end{array}$ & $D=26-40$ & $D=30-50$ & 1 & $1 / 1$ & $\begin{array}{l}\text { when the right-turning } \\
\text { traffic volume is large }\end{array}$ & $\begin{array}{l}\text { partial control is } \\
\text { possible }^{\mathrm{e}}\end{array}$ \\
\hline $\begin{array}{l}\text { Two lane small } \\
\text { roundabout (see Figure } 1 \\
\text { c) }\end{array}$ & $D=40-60$ & $D=45-60$ & 2 & 1 or $2 / 1$ & $\begin{array}{l}\text { when the right-turning } \\
\text { traffic volume is large }\end{array}$ & $\begin{array}{l}\text { partial control is } \\
\text { possible }^{\mathrm{e}}\end{array}$ \\
\hline $\begin{array}{l}\text { Large roundabout }^{\mathrm{b}} \\
\text { (see Figure } 1 \mathrm{~d} \text { ) }\end{array}$ & $\mathrm{D}>50 \mathrm{~m}^{\mathrm{c}}$ & & undefined & undefined & undefined & suggested \\
\hline $\begin{array}{l}\text { Turbo roundabout }{ }^{\mathrm{d}} \\
\text { (see Figure } 1 \mathrm{e} \text { ) }\end{array}$ & $\begin{array}{l}\text { Non typical ova } \\
\text { design different } \\
\text { are used. Their } \\
\text { the type of turb }\end{array}$ & $\begin{array}{l}\text { shape. In } \\
\text { sizes of radii } \\
\text { ize depends on } \\
\text { roundabout }\end{array}$ & variable $^{f}$ & undefined & undefined & undefined \\
\hline \multicolumn{7}{|c|}{$\begin{array}{l}\text { Notes: Larger diameters than those defined in the above table shall be used only in exceptional case and where no pedestrian and bicycle traffic is } \\
\text { planned. } \\
\text { a The inner island of a very small roundabout is traversable. } \\
\text { b Though a large traffic-light controlled roundabout has good safety and traffic quality, construction of a new roundabout shall be discussed only in } \\
\text { exceptional case. } \\
\text { c The maximum outside diameter has not been regulated. However, a very large outside diameter ( } D>80 \mathrm{~m}) \text { may cause problems due to a large area } \\
\text { taken by a roundabout and high driving speeds. } \\
\text { d Traffic flows in those roundabouts are separated when entering the roundabout, circulating around it or leaving it. The lane dividers shall be installed } \\
\text { from granite, stone or reinforced concrete, in exceptional cases the dividers can be erected by milling road pavement. } \\
\text { e Partial control can be used to "dose" traffic flow where there are large separate pedestrian and bicycle flows at the crossings. Also, in order to protect } \\
\text { and fasten the traffic of public vehicles. } \\
\text { } \text { By the type of turbo roundabout a circular carriageway is made of one and two, or two and three traffic lanes. }\end{array}$} \\
\hline
\end{tabular}

a)

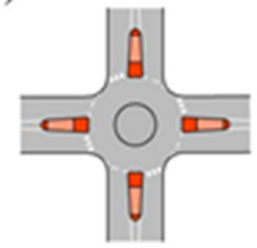

c)

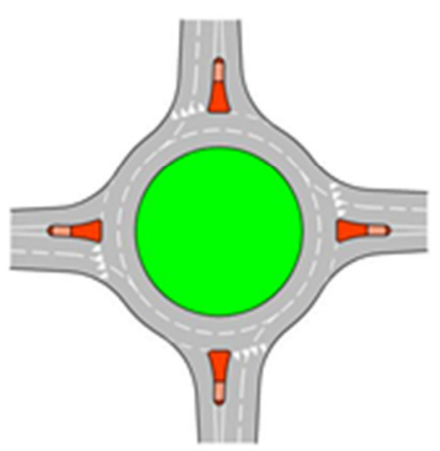

b)

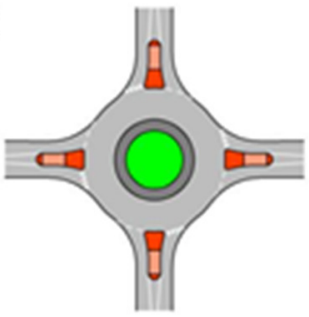

d)

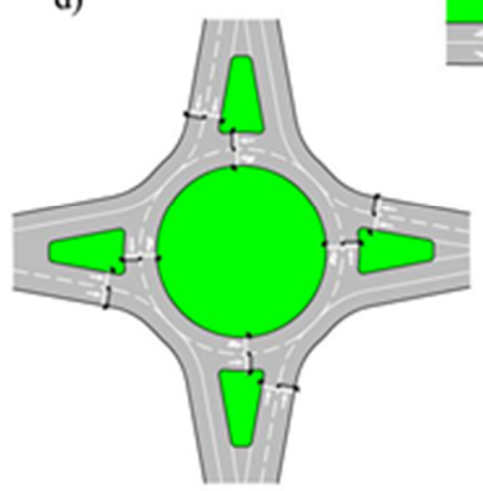

e)

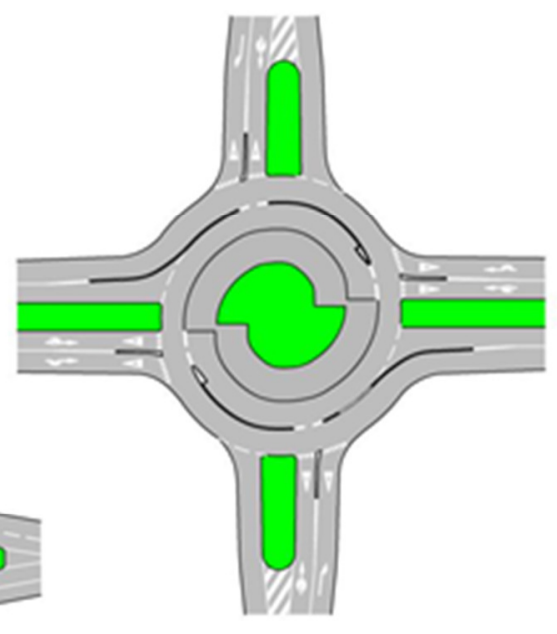

Fig. 1. Roundabout type: mini roundabout (a); small roundabout (b); two lane small roundabout (c); large roundabout (d); turbo roundabout (e)

\section{Regulations for the pedestrians and bicyclists at roundabouts in Lithuania}

The new methodical guidelines give detailed regulations on when and how pedestrian crossings or passages shall be installed.

When designing and building roundabouts all the related unsafe pedestrian crossings shall be eliminated, and the roundabouts themselves shall become even safer. For example, there is a regulation that pedestrian and bicycle traffic in a 
turbo roundabout should be organized by installing grade-separated crossings. In other cases, a safety island of the certain minimum width shall be built.

The guidelines set detail and clear regulations on the organization of bicycle traffic by the carriageway. Bicycle traffic in the mixed flow of circular carriageway is allowed only if the total traffic volume of the roundabout is less than 10000 $\mathrm{veh} /$ day. It is also necessary to restrict as much as possible the overtaking of bicyclists (e.g. to frame the inner island with non-traversable kerbs).

A priority of bicyclists has been also defined. The regulation is set which will help to avoid dangerous driving of bicyclists having no priority right. From now, the roads signs No. 203 "Give way" can be used also at the bicycle tracks to timely attract the bicyclists' attention and to give way to the motor vehicles.

It is established that when entries have two traffic lanes, pedestrian crossings are installed only in exceptional cases, and bicycle traffic cannot be given a priority.

\section{Conclusions}

1. A rational use of roundabouts ensures a required capacity of intersecting traffic flows and reduces accident risk to minimum.

2. Methodical Guidelines for the Design of Roundabouts MN ŽSP 12 establish that the roundabouts are classified into 5 types and gives detail regulations on their design elements.

3. It was determined that the diameter of roundabouts depends on the type of roundabout and also on the location (builtup or unbuilt area) where it is planned. The outside diameter varies from $13 \mathrm{~m}$ (a very small roundabout in built-up area) up to $60 \mathrm{~m}$ (a two lane small roundabout in unbuilt area). The maximum outside diameter of a large roundabout (built only in exceptional cases) is not limited but larger than $80 \mathrm{~m}$ is not recommended.

4. From the point of view of traffic safety it is required that the exits of very small and of both types small roundabouts shall always have only one traffic lane.

5. Taking into consideration the traffic safety situation in Lithuania it was decided to prohibit construction of bicycle lanes in a circular carriageway. The bicyclists are allowed to drive in the mixed flow only if the total traffic volume of the roundabout is $\leq 10000 \mathrm{veh} /$ day and having restricted their overtaking.

\section{References}

[1] Jasiūnienè, V.; Čygas, D.; Ratkevičiūte, K.; Peltola, H. 2012. Safety ranking of the Lithuanian road network of national significance, Baltic journal of road and bridge engineering 7(2): 129-136.

[2] Laurinavičius, A.; Grigonis, V.; Ušpalytė-Vitkunienè, R.; Ratkevičiutè, K.; Čygaitè, L.; Skrodenis, E.; Antov, D.; Smirnovs, J.; Bobrovaitè-Jurkonè, B. 2012. Policy Instruments for Managing Eu Road Safety Targets: Road Safety Impact Assessment, Baltic journal of road and bridge engineering 7(1): 60-67.

[3] Wang, Y.; Bai, H.; Xiang, W. 2011. Traffic Safety Performance Assessment and Multivariate Treatments for Intersection Locations, Baltic journal of road and bridge engineering 6(1): 30-38.

[4] Skrodenis, E.; Venckauskaite J.; Burinskienè M. 2009. Substantiation of Communication Infrastructure Selection in Newly Developed Territories, Baltic journal of road and bridge engineering 4(2): 87-94.

[5] Antov, D.; Abel, K.; Surje, P.; Rouk, H.; Roivas, T. 2009. Speed reduction effects of urban roundabouts, Baltic journal of road and bridge engineering 4(1): 22-26.

[6] Skrodenis, E.; Vingrys, S.; Pashkevich, M. 2011. Lithuanian experience of implementation of roundabouts: the research of accidents, operation and efficiency, in The $8^{\text {th }}$ international conference Environmental Engineering, 980-985.

[7] Klibavičius, A. 2008. Simulation of capacity of roundabouts applying principles of sustainable urban development, in The $7^{\text {th }}$ international conference Environmental Engineering, 975-980.

[8] Corriere, F.; Guerrieri, M. 2012. Performance Analysis of Basic Turbo-Roundabouts in Urban Context, in SIIV-5th International Congress Sustainability of Road Infrastructures 53: 622-632.

[9] Tollazzi, T.; Rencelj, M.; Turnsek, S. 2011. Slovenian experiences with alternative types of roundabouts - "Turbo" and "Flower" roundabouts, in The $8^{\text {th }}$ international conference Environmental Engineering, 1220-1226.

[10] Tracz, M.; Splawinska, M.; Wozniak, K. 2005. New developments in the design of small roundabouts, in The $6^{\text {th }}$ international conference Environmental Engineering.

[11] Koren, C.; Toth-Szabo, Z. 2008. The first experiences with signalised roundabouts in Hungary, Transport Research Arena Europe, 10.6.8 paper 0133.

[12] Daniels, S.; Brijs, T.; Nuyts, E.; Wets, G. 2009. Injury crashes with bicyclists at roundabouts: influence of some location characteristics and the design of cycle facilities, Journal of Safety Research 40(2): 141-148. http://dx. doi.org/10.1016/j.jsr.2009.02.004

[13] Daniels, S.; Brijs, T.; Nuyts, E.; Wets, G. 2011. Extended prediction models for crashes at roundabouts, Safety Science 49(2): $198-207$. http://dx.doi.org/10.1016/j.ssci.2010.07.016

[14] Automobiliu keliu sankryžos R-36.

[15] Inžineriniu saugaus eismo priemoniu projektavimo ir naudojimo rekomendacijos MN ŽSP 12.

[16] Žilionienè, D.; Oginskas, R.; Petkevičius, K. 2010. Research, analysis and evaluation of roundabouts constructed in Lithuania, Baltic journal of road and bridge engineering 5(4): 240-245. 